\title{
Medisinske funn etter voldtekt
}

\section{Klamydia ble sjelden påvist, det var vanlig med funn av etanol, og spor- sikringsanalyse og moderat skade på fornærmedes kropp predikerte tiltale i voldtektssakene.}

Overgrepsmottaket ved St. Olavs hospital i Trondheim har siden 1989 tilbudt helsehjelp og rettsmedisinsk undersøkelse til dem som har vært utsatt for seksuelle overgrep. Utbredelse av seksuelt overførte infeksjoner og hvilke toksikologiske agenser som kan påvises etter voldtekt i Norge har hittil vært lite studert. Det er dessuten begrenset kunnskap om hvorvidt politiet og rettsvesenet har benyttet seg av medisinsk informasjon.

Formålet med studien var å beskrive forekomsten av seksuelt overførbare infeksjoner og toksikologiske prøvesvar samt skader og funn av sæd og DNA hos fornærmede. Er det sammenheng mellom medisinske funn og rettslig utfall i voldtektssakene?

I doktorarbeidet mitt ble data fra sykehusog politijournaler for perioden 1997-2010 innhentet.

$9 \%$ fikk påvist seksuelt overførte infeksjoner, men bare et fåtall var blitt smittet under overgrepet. $22 \%$ mistenkte at de hadde vært utsatt for ufrivillig påført bedøvelse. Noen av disse testet positivt for sedativer, men vi kunne som regel ikke utelukke frivillig inntak. $85 \%$ av dem som ble testet innen 12 timer fikk påvist etanol i blodet alkoholkonsentrasjonen under overgrepet ble beregnet til gjennomsnittlig 1,9\%o. Bare $11 \%$ av de anmeldte voldtektssakene endte i retten. I disse sakene forelå det oftere sporsikringsanalyse og dokumentasjon på moderat skade på fornærmedes kropp enn i de sakene som ikke havnet i retten.

Både helsevesenet og politiet kan dra nytte av bedre samarbeid og utveksling av kunnskap for i siste instans å optimalisere forholdene for ofre for seksuelle overgrep.

Cecilie Therese Hagemann cecilie.hagemann@ntnu.no

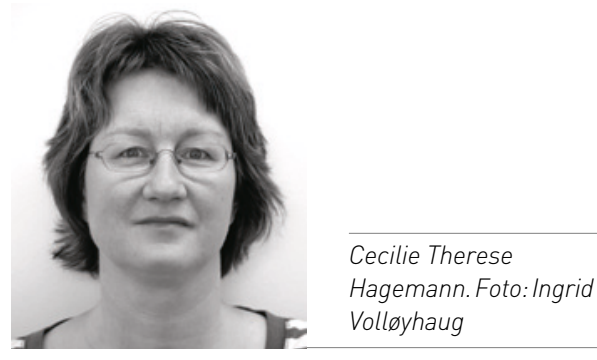

Disputas

Cecilie Therese Hagemann disputerte for ph.d.graden ved Norges teknisk-naturvitenskapelig universitet 14.11. 2014. Tittelen på avhand-

lingen er Medical findings and legal outcome among postpubertal women attending the Sexual Assault Centre at St. Olavs Hospital, Trondheim, Norway. A record-based study from 1997-2010.

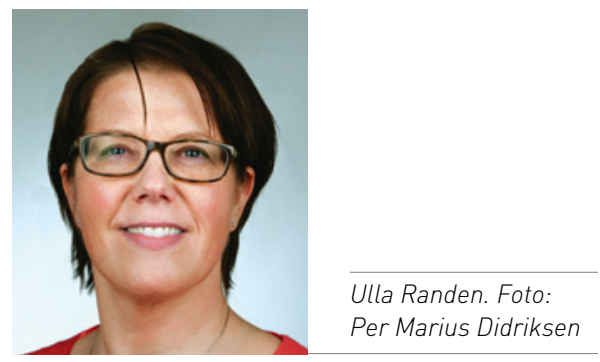

Disputas

Ulla Randen disputerte for ph.d- graden ved Universitetet i Oslo 12.12. 2104. Tittelen på avhandlingen er Small B-cell lymphoproliferative disorders: further characterization of novel subtypes. effekt på symptomene.

I doktorarbeidet mitt undersøkte vi beinmargsbiopsier, beinmargsaspirater og blodprøver fra pasienter med kronisk kuldeagglutininsykdom og inkluderte molekylærgenetiske analyser som både bidro til å karakterisere tilstanden og til å forklare patogenesen. Vi fant at alle pasientene har den samme

klonale lymfoproliferative sykdommen, og at den skiller seg fra alle hittil beskrevne lymfomer. Mutasjon av genet MYD88, som er typisk for lymfoplasmacyttisk lymfom/ Waldenströms sykdom, ble ikke påvist. Bcellene brukte også en annen del av immunglobulingenet (IGHV4-34) enn andre typer lymfomer. En klinisk studie med kombinert rituksimab- og fludarabinterapi viste bedre effekt enn rituksimab monoterapi, muligens som følge av effekten på plasmacellene.

Funnene viser at pasienter med kronisk kuldeagglutininsykdom har en særegen lymfoproliferativ tilstand som ikke passer med noen annen lymfomtype, og at kombinasjonsbehandling med antistoff og cytostatika gir god respons.

Ulla Randen

uranden@ous-hf.no 